\title{
Three New Maize Hybrids for Afghanistan
}

\author{
Rajiv Sharma ${ }^{1}$, Qudratullah Soofizada ${ }^{2}$, Mohammad Hashim Azmatyar $^{2} \&$ Elias Mohmand $^{1}$ \\ ${ }^{1}$ International Maize \& Wheat Improvement Center (CIMMYT)-Afghanistan, Kabul, Afghanistan \\ ${ }^{2}$ Agricultural Research Institute of Afghanistan (ARIA), Kabul, Afghanistan \\ Correspondence: Rajiv Sharma, International Maize \& Wheat Improvement Center (CIMMYT)-Afghanistan, \\ Kabul, Afghanistan. E-mail: rk.sharma@cgiar.org
}

Received: January 29, 2018

Accepted: April 2, $2018 \quad$ Online Published: May 15, 2018

doi:10.5539/jas.v10n6p349

URL: https://doi.org/10.5539/jas.v10n6p349

\begin{abstract}
Afghanistan grows maize in about $0.15 \mathrm{~m}$ ha with an annual production hovering around 300,000 tonnes. The country does not have any officially released commercial maize hybrid and relies only on open pollinated varieties for cultivating maize. The countries in region enjoy much higher productivity levels ranging from 3.5 to 5.00 tonnes per ha compared to 2.2 tonnes per ha of Afghanistan. Several maize hybrids were introduced from CIMMYT to test them for adaptation and yielding ability in Afghanistan for the purpose of releasing them in the country. The three public sector maize hybrids described in this communication were tested at several locations viz., Nangarhar province, Kabul, Baghlan and Helmand in Afghanistan during 2012 to 2014 crop seasons. The hybrids/inbreds bred by CIMMYT were tested against the currently grown open pollinated (OP) varieties and they yielded on an average 31 to $38 \%$ higher than the currently popular open pollinated maize varieties. The hybrids were released for commercial cultivation in 2014.
\end{abstract}

Keywords: maize, Zea mays, hybrids, Afghanistan, CIMMYT

\section{Introduction}

Maize (Zea mays) is the third most important cereal crop of Afghanistan after wheat and rice. It covers about $6.5 \%$ of the total cereal area of the country and accounts for about $6.8 \%$ of total cereal production of Afghanistan (APR, 2013). Even though historically maize has been an important crop of Afghanistan, its production in recent years has not been increasing (Figure 1). Table 1 depicts maize production, productivity figures in the neighboring countries in the region to indicate what should easily be achievable under Afghan agro-climatic conditions with available technology.

Table 1. Maize statistics for Afghanistan and other countries in the region

\begin{tabular}{llll}
\hline Country/Region & Area (m ha) & Yield (t/ha) & Prod. (m tones) \\
\hline Afghanistan & 0.14 & 2.2 & 0.31 \\
Iran & 0.35 & 3.5 & 1.2 \\
Pakistan & 1.1 & 4.6 & 4.3 \\
World + (Total) & 177 & 4.9 & 872 \\
Asia + (Total) & 58 & 5.0 & 289 \\
\hline
\end{tabular}

Maize has more potential than what it has currently been utilized for. The self-sufficiency targets for three and ten-year durations stand at 0.36 and 0.50 million tones. FAO estimated import of 7.6 and 2.9 thousand tonnes of maize with import bills of four and 0.8 million USD in 2009 and 2011, respectively (FAO, 2013). The major challenges facing maize in the country include non-availability of quality seed, appropriate extension activities and non-availability of quality and quantity inputs at the right time. Another important factor responsible for disparity in yield with neighboring countries is that while neighboring countries mostly grow hybrids, there is no commercially available hybrid in Afghanistan and farmers exclusively grow open pollinated (OP) varieties. Hybrids have been in cultivation in many countries for several decades now (Marton, 2013) and have been 
shown to offer upto over $50 \%$ yield advantage (Sharma et al., 2016) with yield potential ranging from around eight tonnes per hectare to over ten tonnes per hectare (Tripathi et al., 2016). As a matter of fact varietal development work in Afghanistan has so far concentrated only on development of OP varieties (Obaidi et al., 2012). Maize is a highly remunerative crop for farmers as well as for industry. It is a crop whose all plant parts have specific domestic and/or industrial use. An increase in maize production will not just meet traditional domestic needs but will fuel growth of several industries.

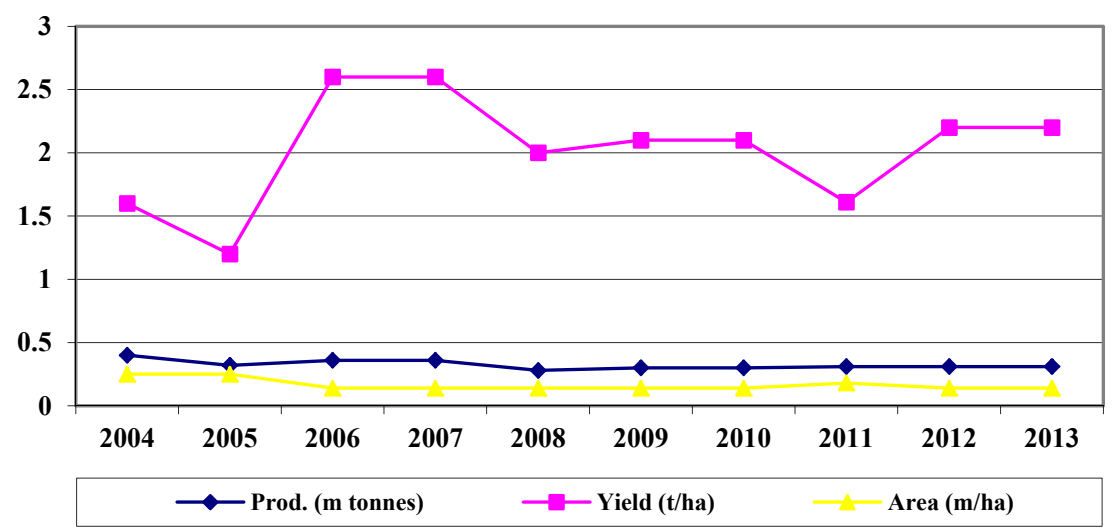

Figure 1. Maize statistics for Afghanistan

This paper reports introduction, evaluation and release of three maize hybrids for commercial cultivation in Afghanistan. These are first ever maize hybrids officially released by Ministry of Agriculture, Irrigation and Livestock (2013) of the Government of Afghanistan to further boost maize production in Afghanistan.

\section{Materials and Methods}

A large number of maize hybrids were introduced from the international maize breeding facilities of CIMMYT located in Africa. A total of 15 hybrids were tested in preliminary yield trial (PYT) at two locations in Nangarhar during 2012 with three OP varieties as checks (Table 2).

Table 2. Summary of three years' yield evaluation trials of new hybrids

\begin{tabular}{llll}
\hline Year & $\mathbf{2 0 1 2}$ & $\mathbf{2 0 1 3}$ & $\mathbf{2 0 1 4}$ \\
\hline No. of Locations & 2 & 5 & 3 \\
Number of entries & 15 & 15 & 10 \\
Highest yielder & $\mathrm{CH} 102029$ & $\mathrm{CH} 123$ & $\mathrm{CH} 123$ \\
Average Yield (tonnes/ha) & 6.1 & 10.1 & 8.7 \\
Yield range (tonnes/ha) & 7.4 to 4.5 & 11.6 to 7.2 & 10.2 to 7.2 \\
Least significant difference at 5\% (tonnes/ha) & 0.63 & 1.4 & 0.99 \\
\hline
\end{tabular}

The promising hybrids and few more totaling 15 entries were again tested in an advance yield trial (AYT) at five locations in 2013. Similarly, a final year trial utilizing seven promising hybrids and three OP varieties were tested at three locations in 2014. Trials were conducted during maize growing season (Jun to October) using a randomized completed block design in three replications. All recommended agronomic practices were adopted in conducting the trials. A basal dose of $200 \mathrm{Kg} / \mathrm{ha}$ of DAP was applied and urea at the rate of $72 \mathrm{Kg} / \mathrm{ha}$ was applied in two split doses after thinning of the maize when the plants were of around $30 \mathrm{~cm}$ height and at silk stage. The experimental plots were hand weeded and thinning was done when all seedlings had fully emerged.

Observations were recorded on days to flowering (male and female) when $75 \%$ of the plants in a plot had fully emerged, number of plants, number of harvested plants and ears, and plant height at maturity. Days to maturity was recorded when abscission layer was formed at the bottom of kernel. Plants were hand harvested. Field 
weight $(\mathrm{cob}+$ grain) at different moisture content and grain weight after sun drying were recorded. Analysis of variance (ANOVA) was conducted for each site for all the years (Table 2). Pooled ANOVA across sites was also worked out.

\section{Result and Discussion}

Maize hybrids are being increasingly used by farmers in the region (CIMMYT, 2016). Maize hybrids occupy about $90 \%$ of maize acreage in Pakistan and 95\% in China. The hybrids are increasingly being assessed for their adaptation to drought and other stresses in the region (Emdad \& Fardad, 2000). In comparison, Afghanistan is still having all its maize acreage under OP varieties and is therefore stagnant at poor maize yields. CIMMYT maize hybrids have been highly successful in several regions of the world. A recent study (Masuka et al., 2017) estimated that between 2000 and 2010 CIMMYT maize hybrids gave yield gain of about $100 \mathrm{Kg} / \mathrm{ha} / \mathrm{year}$ in Eastern and Southern Africa. With an objective to assess adaptation in Afghanistan, the introduced hybrids were tested at several locations in Afghanistan over a three year period (Table 2). The testing sites included research stations of Agricultural Research Institute of Afghanistan at Jalalabad, Baghlan, Kabul and Helmand. Trials were also conducted at farms of Private Seed Enterprises (PSE) in Nangarhar. The first year preliminary yield trial (PYT) of 15 maize hybrids with three OP varieties as check was conducted at two locations in Nangarhar in 2012. The hybrid CH 102029 yielded highest followed by hybrid CH 124. Hybrids yielded an average of $6.9 \mathrm{t} / \mathrm{ha}$ as compared to $5.5 \mathrm{t} / \mathrm{ha}$ of OP varieties. The second year trial viz., Advance yield trial (AYT) with 15 hybrids and three OP varieties as checks was conducted at five locations in Afghanistan viz., Kabul, Baghlan, Helmand and two locations in Nangarhar. The hybrids displayed very high superiority over open pollinated check varieties. The highest yield was recorded for CH124. The hybrids yielded an average of $11.1 \mathrm{t} / \mathrm{ha}$ compared to $7.4 \mathrm{t} / \mathrm{ha}$ recorded for OP check varieties. The trial was again tested for third year at two locations during 2014 as a National Uniformity Trial (NUT). The highest yield among the contending hybrids was again recorded for $\mathrm{CH}$ 124. The OP varieties yielded an average of $7.2 \mathrm{t} / \mathrm{ha}$ in NUT whereas hybrids average was $9.6 \mathrm{t} / \mathrm{ha}$. The hybrids scored a superiority of $27 \%, 50 \%$ and $32 \%$ during first, second and third year of trials, respectively (Fig 2 ). The three year average estimates revealed that hybrids yielded $37 \%$ higher at $9.2 \mathrm{t} / \mathrm{ha}$ over OP varieties which yielded an average of $6.7 \mathrm{t} / \mathrm{ha}$ (Table 2). The three hybrids have yielded 31 to $38 \%$ higher than the currently popular open pollinated maize varieties of Afghanistan.

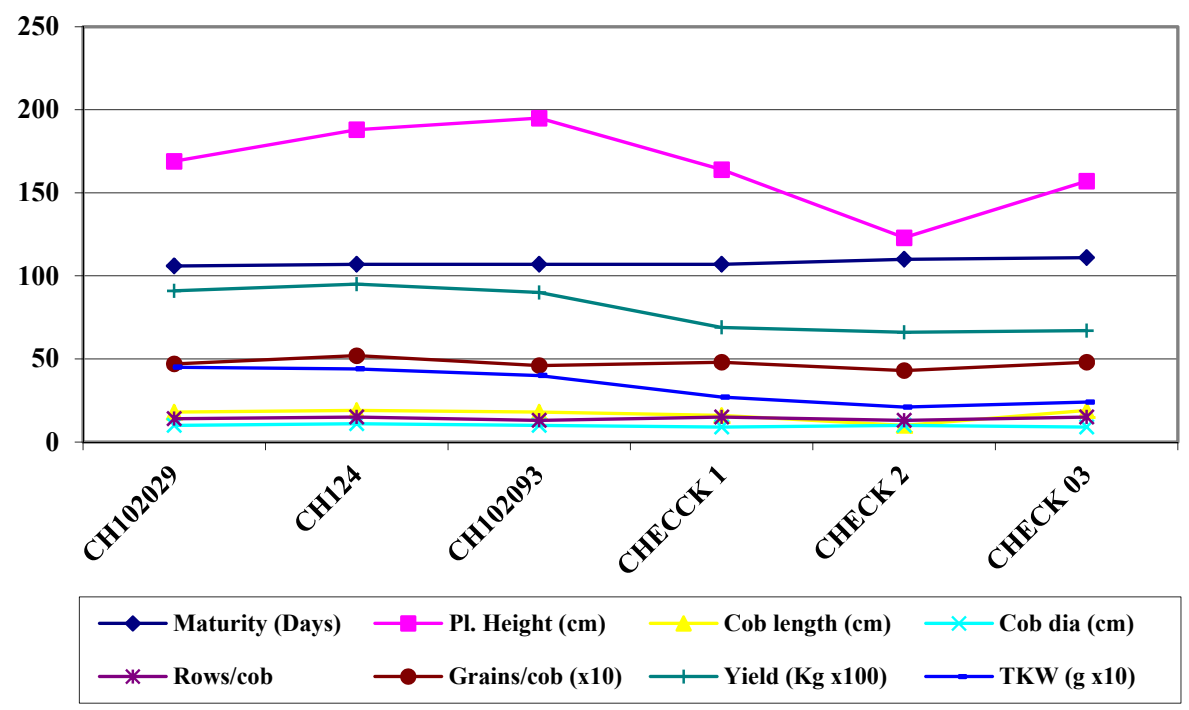

Figure 2. Comparison of new hybrids with checks used

The overall mean yield across three years indicated that hybrids yielded 31 to $38 \%$ higher than the best check variety (Table 3). Even though, they were higher yielder but they matured four to five days earlier than the OP varieties (Table4). 
Table 3. Performance $(\mathrm{Kg} / \mathrm{ha})$ of released maize hybrids and check varieties over three year period

\begin{tabular}{lllllll}
\hline No. & Pedigree & $\begin{array}{l}\mathbf{2 0 1 2} \\
\text { (PYT-Hybrid Maize) }\end{array}$ & $\begin{array}{l}\mathbf{2 0 1 3} \\
\text { (AYT-Hybrid Maize) }\end{array}$ & $\begin{array}{l}\mathbf{2 0 1 4} \\
\text { (NUT-Hybrid Maize) }\end{array}$ & $\begin{array}{l}\text { Average } \\
\text { \% Over } \\
\text { Best check }\end{array}$ \\
\hline $\mathbf{1}$ & CH102029 & 7406 & 11016 & 8895 & 9106 & 133 \\
$\mathbf{2}$ & CH124 & 7152 & 11468 & 9930 & 9517 & 139 \\
$\mathbf{3}$ & CH102093 & 6380 & 10844 & 9907 & 9044 & 132 \\
$\mathbf{4}$ & Shamal.08 (Check)* & 5987 & 7449 & 7157 & 6864 & 100 \\
$\mathbf{5}$ & SHARQ.08 (Check) & 5172 & 7190 & 7365 & 6576 & 96 \\
$\mathbf{6}$ & Zoodras (Check) & 5301 & 7589 & 7224 & 6705 & 98 \\
\hline
\end{tabular}

Table 4. Agronomic characters of hybrids and check varieties

\begin{tabular}{lllllllllll}
\hline Genotype & $\begin{array}{l}\text { Days } \\
\text { to Tassel }\end{array}$ & $\begin{array}{l}\text { Days } \\
\text { to silk }\end{array}$ & $\begin{array}{l}\text { Days to } \\
\text { Maturity }\end{array}$ & $\begin{array}{l}\text { Plant } \\
\text { height } \\
(\mathbf{c m})\end{array}$ & $\begin{array}{l}\text { Lodging } \\
(\%)\end{array}$ & $\begin{array}{l}\text { Cob } \\
\text { Diameter } \\
\text { (cm) }\end{array}$ & $\begin{array}{l}\text { Cob } \\
\text { Length } \\
\text { (cm) }\end{array}$ & $\begin{array}{l}\text { No of } \\
\text { rows } \\
\text { per cob }\end{array}$ & $\begin{array}{l}\text { No of } \\
\text { grains } \\
\text { per cob }\end{array}$ & $\begin{array}{l}\text { Thousand } \\
\text { Kernel } \\
\text { weight (g) }\end{array}$ \\
\hline CH102029 & 57 & 61 & 106 & 169 & 0 & 10 & 18 & 14 & 471 & 450 \\
CH124 & 59 & 62 & 107 & 188 & 0 & 11 & 19 & 15 & 525 & 436 \\
CH102093 & 59 & 62 & 107 & 195 & 0 & 10 & 18 & 13 & 465 & 395 \\
ZOODRAS (Check) & 54 & 58 & 107 & 164 & 0 & 9 & 16 & 15 & 478 & 273 \\
SHAMAL.08 (Check) & 58 & 61 & 110 & 123 & 0 & 10 & 10 & 13 & 434 & 212 \\
Sharq-08 (Check) & 58 & 61 & 111 & 157 & 0 & 9 & 19 & 15 & 477 & 245 \\
Average & 58 & 61 & 108 & 166 & 0 & 10 & 17 & 14 & 475 & 335 \\
\hline
\end{tabular}

The comparable maturity would ensure an accelerated adoption by farmers. Though the cob length and number of rows per cob were comparable between hybrids and OP, the former were taller than the latter giving more fodder and had much higher 1000 grain weight. The maize hybrids have been found to benefit even small farmers as well (Schroeder et al., 2013), therefore, the hybrids were released for commercial cultivation to help farmers harvest higher yields per unit area and time compared to any other variety available in the country.

\section{References}

Ministry of Agriculture, Irrigation and Livestock. (2013). Agriculture Prospect Report. Ministry of Agriculture, Irrigation and Livestock, Afghanistan. Retrieved from http://mail.gov.af/en/page/3489/agriculturalprospect-reports

CIMMYT. (2016). Economic projections of Pakistan's maize sector. Retrieved from http://repository.cimmyt. org/xmlui/bitstream/handle/10883/18890/58256.pdf?sequence=1

Emdad, M. R., \& Fardad, H. (2000). Effect of salt and water stress on corn yield production. Iranian Journal of Agricultural Sciences, 31(3), 641-654.

FAO. (2013). Retrieved May 3, 2014, from http://www.faostat3.fao.org

Marton, C. L. (2013). Hybrid maize in Hungary is 60 year old. In L. C. Marton \& T. Spitko (Eds.), 60 years of Hungarian Hybrid Maize 1953-2013 (pp. 10-16). Hybrid Maize Conference, Martonvasar, Hungary.

Masuka, B., Atlin, G. N., Olsen, M., Magorokosho, C., Labuschagnee, M., Crossa, J., ... Cairns, J. E. (2017). Gains in maize genetic improvement in eastern and Southern Africa: 1. CIMMYT hybrid breeding pipeline. Crop Sci., 57(1), 168-179. https://doi.org/10.2135/cropsci2016.05.0343

Obaidi, M. Q., Osmanzai, M., \& Sharma, R. (2012). Zoodras-A new high yielding maize variety for Afghanistan. Americal-Eurasian J. Agric. \& Env. Sci., 12, 1242-1245. https://doi.org/10.5829/idosi.aejaes. 2012.12.09.1842

Schroeder, C., K'Oloo, T. O., Bahadur, R. N., Jick, N. A., Parzies, H. K., \& Gemenet, D. C. (2013). Potentials of hybrid maize varieties for small-holder farmers in Kenya: A review based on SWOT analysis. African J. of Food, Ag. Nutrition and Dev., 13(2), 7562-7586. 
Sharma, H. P., Dhakal, K. H., Kharel, R., \& Shrestha, J. (2016). Estimation of heterosis in yield and yield attributing traits in single cross hybrids of maize. J. of Maize Res. \& Dev., 2(1), 123-132. https://doi.org/10.3126/jmrd.v2i1.16223

Tripathi, M. P., Shrestha, J., \& Gurung, D. B. (2016). Performance evaluation of commercial maize hybrids across diverse Terai environments during the winter season in Nepal. J. of Maize Res. \& Dev., 2(1), 1-12. https://doi.org/10.3126/jmrd.v2i1.16210

\section{Copyrights}

Copyright for this article is retained by the author(s), with first publication rights granted to the journal.

This is an open-access article distributed under the terms and conditions of the Creative Commons Attribution license (http://creativecommons.org/licenses/by/4.0/). 